\title{
Determinants of Maize Market Supply, Production and Marketing Constraints: The Case of Dembecha District, West Gojjam Zone, Ethiopia
}

\author{
Desalegn Wondim ${ }^{1,}$, , Tewodros Tefera ${ }^{2}$, Yitna Tesfaye ${ }^{2}$ \\ ${ }^{1}$ Department of Agribusiness and Value Chain Management, Burie Campus, Debre Markos University, Burie, Ethiopia \\ ${ }^{2}$ School of Environment, Gender and Development Studies, Hawassa University, Hawassa, Ethiopia \\ Email address: \\ desalegnwondim@yahoo.com (D. Wondim),dagted@gmail.com (T. Tefera), yitnatesfaye@gmail.com (Y. Tesfaye) \\ *Corresponding author
}

\section{To cite this article:}

Desalegn Wondim, Tewodros Tefera, Yitna Tesfaye. Determinants of Maize Market Supply, Production and Marketing Constraints: The Case of Dembecha District, West Gojjam Zone, Ethiopia. International Journal of Economy, Energy and Environment.

Vol. 5, No. 5, 2020, pp. 83-89. doi: 10.11648/j.ijeee.20200505.13

Received: July 22, 2020; Accepted: August 31, 2020; Published: October 7, 2020

\begin{abstract}
West Gojjam is one of the maize belt zones in Ethiopia, and Dembecha district is among the potential districts in West Gojjam zone. However, despite its maize production potential of the district, marketed supply determinants, maize production and marketing constraints hampered producer's decision and engagement on maize production and marketing. Thus, this study was attempts to address the determinants of marketed supply of maize, constraints and opportunities in Dembecha district in the year 2018. Data were collected from primary and secondary sources using appropriate tools. Primary data were collected from randomly selected 155 maize producers, 20 consumers as well as 40 maize grain traders, 10 alcohol processors using semi-structured questionnaire. Multiple linear regression econometric model were employed for data analysis owing to all respondents were participating in maize production and marketing activities. Results from econometric model revealed that sex of house hold head at $5 \%$, education at $5 \%$, amount of maize produced at $1 \%$, extension contact at $1 \%$, livestock owned at 5\%, credit use at $10 \%$ and amount of non-farm income at $5 \%$ were positively determine maize marketed surplus in Dembecha district. Land shortage, price of improved seed, road and lack of government support were among major maize production and marketing constraints. Existence of strong multipurpose farmer's cooperatives, using maize for multipurpose in the area and its productivity per hectare were the major opportunities in the study area. Thus, governmental and non-governmental organization that working with relating to maize production and marketing activities in the district should take in to account these determinate factors, constraints and opportunities while preparing intervention strategies.
\end{abstract}

Keywords: Maize, Determinant, Market Supply, Constraints

\section{Introduction}

Agriculture is still the backbone of Ethiopia's economy and it contributes 36.2 percent of the country's gross domestic product (GDP) and 72.7 percent of employment and 70 percent of export earnings [3]. Grain production in Ethiopia is almost entirely based on rain-fed agriculture and is characterized by a dominant harvest (meher) in November and December and a secondary harvest (belg) in April and May and Cereals contributed 87.29\% (about $177,613,365.84 q t)$ of the grain production and maize alone accounts for $(24.5 \%)$ of cereals production in the country [4]. Maize is the most important staple food crop in SubSaharan African countries with few countries on the take-off to export to the neighborhood countries [6]. Ethiopia is the fourth largest maize producing country in Africa, and the first in East African region and produces non-genetically modified (GMO) white maize, the preferred type of maize in neighboring markets [8]. According to [5] report, cereals are the major food crops both in terms of the area planted and volume of production obtained of which maize accounts $16.98 \%$ (about 2,135,571.85 hectares) area coverage less than teff which is $24.00 \%$ (about 3,017,914.36 hectares but 
obtained $27.02 \%(78,471,746.57$ quintals $)$ production greater than teff which is $17.29 \%(50,204,400.47$ quintals $)$. The same report, in 2016/17 production year the top three maize producer parts of Ethiopia namely, Amhara, Oromia and Southern region respectively accounting for $8.94 \%, 7.96 \%$, $7.41 \%$ of grain production in $2015 / 16$.

Table 1. Crops production for private peasant holdings for Meher season 2016/17.

\begin{tabular}{llll}
\hline Cereals & Area in hectares & Production in quintals & Yield (Qt/Ha) \\
\hline Teff & 3017914.36 & 50204400.47 & 16.64 \\
Barley & 959273.36 & 20249216.76 & 21.11 \\
Wheat & 1696082.59 & 45378523.39 & 26.75 \\
Maize $^{\mathrm{a}}$ & 2135571.85 & 78471746.57 & 36.75 \\
Maize $^{\mathrm{b}}$ & 519495.17 & 19629371.96 & 37.79 \\
Maize $^{\mathrm{c}}$ & 212556.78 & 8986216.99 & 42.28 \\
\hline
\end{tabular}

Note: in table 1. a, b and c represents Ethiopia, Amhara and West Gojjam in that order.

Source: CSA, 2017.

According to [11] although the extent of cultivation varies, maize is cultivated in some 74 important maize producing administrative zones of the country which 20 contribute almost $80 \%$ of the national production and marketable surplus is mainly produced in these high potential zones of which West Gojjam Zone was the first contributing $11.3 \%$.

Maize is the second in quantity of consumption and the first in terms of its contribution to daily caloric intakes among foods and on average, Ethiopians consume about $42 \mathrm{Kgs}$ of maize per year per person (including maize equivalent of maize products) and maize accounts for about 20 percent of the daily caloric intake [8]. In Ethiopia, although maize is a staple food, consumption is predominant in rural areas and about 5.4 million tons are annually consumed in the country. Population growth, development of the livestock sector particularly poultry and emerging agroprocessing industries are the factors that influence future maize consumption and would likely contribute to increased demand in the country [7].

Numbers of studies conducted, to identify determine of marketed supply of different produces in different parts of the country. For instance, [9] conducted wheat value chain analysis and one of the objectives were to identify the determinants of the supply of wheat in the market, the result of the multiple regression model indicated that volume of marketed is positively and significantly affected by sex of the household heads, utilization of improved seed, lag market price, amount of credit, land size, and livestock holding whereas family size had shown negative and significant relationship with volume of wheat marketed.

[10] Identified the major factors that affect teff and wheat market supply in Dendi district, West Shoa None, Ethiopia. Their study revealed that the quantity of Teffand Wheat produced at the farm level affected marketable supply of Teff and Wheatpositively and significantly. In similar way [12] identified major factors that affect market supply of wheat and the result of econometric multiple regression model indicated that size of landholding, livestock ownership, family size and quantity of wheat produced influences amount of wheat supplied to market significantly. In maize market supply determinants, fertilizer quantity used, current maize price, marketing costs and land allocated determined volume of maize supplied to the market positively whereas non-farm income and distance from the main market determined quantity supply negatively affected quantity of maize supplied in that study area [1].

Shortage of certified maize seeds varieties suitable for different agro ecological zones; inadequate supply and marketing of maize seed; inadequate transport infrastructure and high cost of transport; lack of reliable and timely market information; inadequate access to credit facilities by grain traders; lack of storage and marketing facilities in both the surplus producing and the consumption centres etc. are some of the constraints in maize production and marketing performance in Ethiopia [11].

According to [3] the level of cereal availability in the market, especially maize and sorghum are low in 2017 , both in surplus and deficit areas because of unusual and unexpected high official and informal exports (especially maize). The price of maize increases over the last years, wholesale maize prices have increased sharply from $\$ 21.83$ in 2016 to over $\$ 39.30$ per quintal in mid-2017 due to the main reason for this sharp increase in maize prices is Tanzania's maize export ban, which led to increased demand for maize within the region and expansion of cross border trade between Kenya and Ethiopia, exerting pressure on domestic maize prices and an increase in exports to the Southern Africa countries as initiated opportunity.

Even though various researches related to the topic were conducted in different parts of Ethiopia and results reveled that maize supply determinant factors, constraints and opportunities are area specific problems across different maize producing areas and thus, to the best of the researcher's knowledge empirical evidence did not found in the study area. Thus, this study aimed to identify maize market supply determinates as well as major constraints and opportunities in the study area.

\section{Methodology}

\subsection{Description of the Study Area}

Dembecha is currently one of the fourteen woredas in West Gojjam Zone of the Amhara Region of Ethiopia. The Woreda had 29 Kebeles of which 25 were rural and 4 were urban and had a total population of 151,023 of which 75559 were men and 75464 were women. From this total population, 14\% (21143) were urban dwellers whereas 86\% (129880) were rural residents.

The Woreda has an area of 971.29 square kilometers and had a population density of 133 persons per square kilometer and has on average 4 persons per household. The woreda agro ecology comprises Woinadega (83\%), kola $(6 \%)$ and Dega (11\%). Regarding its topographical structure $60 \%$ of the woreda is plane whereas $6 \%$ and $34 \%$ are valley and hill 
respectively (Source: Dembecha woreda office of Agriculture, 2018).

Table 2. Common cereal crops in the Woreda.

\begin{tabular}{lllllll}
\hline \multirow{2}{*}{ Major crops } & $\mathbf{2 0 1 6}$ & & $\mathbf{2 0 1 7}$ & $\mathbf{2 0 1 8}$ & \\
\cline { 2 - 7 } & Area (Ha) & Production in quintal & Area $(\mathbf{H a})$ & Production in quintal & Area (Ha) & Production in quintal \\
\hline Maize & 13047 & 902430.75 & 15434 & 1095939.72 & 16481.97 & 1186701.84 \\
Wheat & 7216 & 69095.5 & 7810 & 402448 & 10216 & 5455797 \\
Teff & 6006.75 & 108452 & 6866 & 125052 & 6870 & 134069.38 \\
Barley & 4587.55 & 21997.875 & 4800 & 402437.2 & 4800 & 263302.3 \\
\hline
\end{tabular}

Source: Woreda Office of Agriculture, 2018.

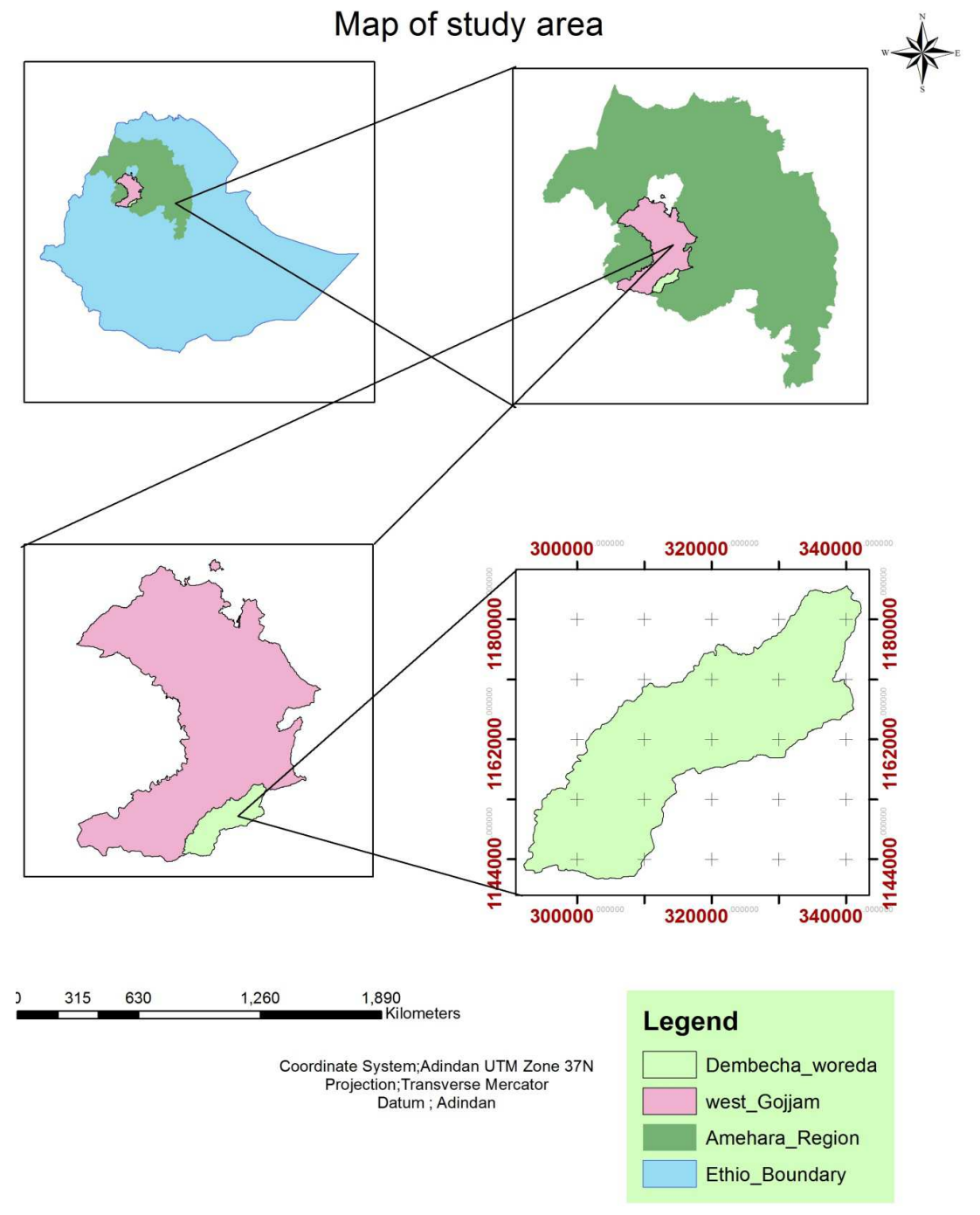

Figure 1. Map of the study area.

\subsection{Types and Sources of Data}

In this study, qualitative and quantitative data types were used from primary and secondary data sources. The primary data were collected from maize producers, traders, processors and consumers. Moreover, all the necessary secondary data on different issues were collected from published and unpublished documents from district office of agriculture and Natural resource annual reports, bulletins, charts posted on the wall of the district office of agriculture, district trade and industry office, websites, CSA data as well as district cooperative's promotion office documents in the study area.

\subsection{Sampling Procedure and Sample Size}

Dembecha woreda was selected purposively because of its maize production potential known from fourteen woredas in West Gojjam zone. By consulting with district agricultural development office the district has currently 25 rural kebeles and almost all kebeles are maize producers of which 14 kebeles are identified (purposively) as highly maize producers. From 14 producer kebeles, four kebeles were selected randomly. Sample size was selected from each 
maize producer Kebeles on the bases of proportional to the size (PPS) sampling technique. Finally, 155 maize producers, 40 maize grain traders, 10 maize processors and 20 consumers selected from the district.

\subsection{Data Collection and Method of Analysis}

A semi structured and independent questionnaire was designed and used for maize producers, maize grain traders, processors and consumers owing to their marketing capacity to purchase and activities were differ. The primary data was collected by the method of individual interview using piloted questionnaire schedule along with observation. Additional data were gathered through informal method of focus group discussion (FGD) and key informant interview using checklist. These informal techniques were also implemented to get additional information during data collection. Two focus group discussions (FGD) were undertaken with a total of 13 members. One with model farmers and experienced maize producers and the other with agricultural development office staffs and Woreda cooperative promotion office to collect additional data on maize producer's constraint and opportunity from input usage and marketing aspect as well as on different issues regarding maize based on the appropriate guideline designed. Key informant interview was conducted with model farmers, cooperatives staff workers (chairman), and district office of agriculture staff workers. The collected data were analyzed using descriptive statistics and econometric model.

\subsection{Econometric Model}

To identify factors that affect marketed supply of maize, multiple linear regression model can be used when all sample producers participate in supply of their produce to the market. But if all producers are not expected to participate in supply of their commodity to the market, using multiple linear regression results excluding the nonparticipants from the analysis and a sample selectivity bias is introduced into a model as different scholars indicated. Therefore, Heckman two stage procedures, Tobit and, Double Hurdle are the common and suggested models to overcome such problems. However, in the study area all sample respondents were found to be participated in maize market. Due to this reason multiple linear regression model was employed to identify determinant factors that affecting volume of market supply of maize in the study area. This model is also selected for its simplicity and practical applicability [2] and econometric model specification of supply function in matrix notation looks like the following.

$$
\mathrm{Y}=\mathrm{X}^{\prime} \beta+\mathrm{U}
$$

Where: $Y=$ quantity of maize supplied to market

$X=$ a vector of explanatory variables

$\beta=$ a vector of parameters to be estimated

$U=$ disturbance term

Hypothesized variables

Table 3. Hypothesis of explanatory variables.

\begin{tabular}{lllll}
\hline Variables & Variable description & Types of variable & Measurement value & Expected sign \\
\hline VMM & Volume of maize marketed & Continuous & Quintal & Depended variable \\
\hline SEXHH & Sex of house hold head & Dummy & $1=$ male, $0=$ female & $+v e$ \\
DISTNM & Distance to the nearest market & Continuous & Minute $/ \mathrm{hr}$ & $-\mathrm{ve}$ \\
FMSZ & Family size & Continuous & Number of family & $+\mathrm{ve} / \mathrm{ve}$ \\
EXCTA & Extension contact & Continuous & Number of visit & $+\mathrm{ve}$ \\
AMTMZP & Amount of maize produced & Continuous & Quintal & $+\mathrm{ve}$ \\
EDUSTHH & Educational status of the house hold head & Dummy & Number of year & $+\mathrm{ve}$ \\
NOFIN & Nonfarm income & Continuous & Ethiopian birr & $+\mathrm{ve} /-\mathrm{ve}$ \\
CRUS & Credit used & Dummy & 1=used credit, not used & $+\mathrm{ve}$ \\
NLSK & Number of live stock holding & Continuous & Total number & $+\mathrm{ve}$ \\
FMEXP & Farming experience & Continuous & Number of year & $+\mathrm{ve}$ \\
AMINFO & Accesses for marketing information & Dummy & 1=Yes, $0=$ No & $+\mathrm{ve}$ \\
\hline
\end{tabular}

\section{Results and Discussion}

Results from demographic analysis from sample respondents in the district showed that $98.1 \%$ and $1.9 \%$ were found to be male and female headed households respectively. Socio economic results in the survey result indicated that, sample respondents had a minimum of 4 and maximum of 36 years of experience in maize production and regarding literacy level, $60 \%$ of sample respondents were literate at different grade level whereas $40 \%$ were illiterate. The average number of total livestock in (TLU) and family size in (adult equivalence) in the district were found to be 10 and 4 respectively. From 155 sample respondents, only $63.9 \%$ households had nonfarm income from different activities $(16.1 \%, 22.6 \%, 0.6 \%, 13.5 \%$, and $11 \%$ from daily labour out of farming activities, firewood sale, carpenter, house rent and petty trade activities respectively). Regarding production, survey result revealed that households produced on average 50 quintals per hectare which is greater than both the national and regional levels of production, 36.75 and 37.79 quintals per hectare [5] respectively. Regarding credit use from different financial institutions, extension contact per the production year and accesses for market information in the district were found to be $71.6 \%, 98.1 \%$ and $71 \%$ of sample households in $2017 / 18$ maize production and marketing year respectively.

Sex of the household head: Sex of household head affects quantity supply positively at less than $5 \%$ significant level. 
The variable signifies that, those male headed households are actively participated in maize production and marketing than female headed households. Result implied, other things remain constant, male headed households supplied 3.22 quintals to the market more than female headed households' maize producers in the study area.

Educational status: As shown in the model result, educational status related with quantity of maize supply to the market affected positively at less than $1 \%$ significant level. The coefficient confirmed that as a household head attend any formal education, it has an effect on farming activity and quantity supply to the market would increase by 1.7 quintals than those who did not attend any formal education in the study area.
Amount of maize produced: Amount of maize produced affects quantity supply to the market positively at $1 \%$ significant level. As the coefficient implied, as quantity of maize produced increased by one quintal the quantity of maize supplied to the market would increase by 0.53 quintal.

Extension contact: As expected, producers who learn and follow extension agent advice produces better amount of maize and this in turn able to supply more to the market. As the model result indicated, extension contact affects amount of maize supply to the market positively at $1 \%$ significant level. As the coefficient revealed as extension agent contact (visit) with maize producers increased by one visit (contact), farmers tends to produce more and in turn amount of supply to the market would increases by 1.32 quintals.

\section{Econometric Analysis}

Table 4. Determinants of producers' marketed surplus of maize (per qt/HH).

\begin{tabular}{|c|c|c|c|c|}
\hline Variables & Coefficient & Robust Std error & t-value & $P>t$ \\
\hline Distance to the nearest market & .0149636 & .0126914 & 1.18 & 0.240 \\
\hline Sex of HHH & $3.225788 * *$ & 1.533871 & 2.10 & 0.037 \\
\hline Educational status & $1.709259 * * *$ & .6169283 & 2.77 & 0.006 \\
\hline Family size & .1728387 & .2767204 & 0.62 & 0.533 \\
\hline Farming experience & -.0418713 & .0394442 & -1.06 & 0.290 \\
\hline maize produced & $.5305517 * * *$ & .0283125 & 18.74 & 0.000 \\
\hline Extension contact & $1.311662 * * *$ & .222818 & 5.89 & 0.000 \\
\hline Nonfarm income & $.0001999 * * *$ & .0000691 & 2.89 & 0.004 \\
\hline Market information & .6096192 & .6236133 & 0.98 & 0.330 \\
\hline Credit use & $1.120941^{*}$ & .5693348 & 1.97 & 0.051 \\
\hline Constant & -13.75097 & 1.70219 & -8.08 & 0.000 \\
\hline \multicolumn{5}{|l|}{$\mathrm{R}^{2} 0.91$} \\
\hline \multicolumn{5}{|l|}{ Observation 155} \\
\hline Mean of VIF 1.20 & & & & \\
\hline
\end{tabular}

$* * *, * *$ and $*$ represents significant at $1 \%, 5 \%$ and $10 \%$ significance levels respectively.

Total livestock Unit: This variable was found to be influenced quantity supply to the market positively at 5\% significant level. It implies Producers having more numbers of different livestock could easily change in to cash and bought different factors of production that able farmers produce and sold more. Furthermore, farmers who have more numbers of livestock can compensate at the time of risk seasons like crop disease, snow or fire. As survey result indicated as numbers of tropical livestock unit producers have increase by one unit, amount of maize supplied to the market would increases by 0.198 quintals with no change made in other things.

Non-farm income: Amount of non-farm income affects quantity of maize supplied to the market positively at $1 \%$ significant level. As shown in the model result coefficient, as the amount of non-farm income of the producers increased by one Ethiopian Birr, amount of maize supplied to the market would increases by 0.0002 quintal.

Maize production and marketing constraints in the district Constraints at producer's level

Price of fertilizers: Price of fertilizers was one of the major constraints that smallholder maize producers reported in the study area. About $86.5 \%$ of sample respondents explained that the price of fertilizers (DAP and Urea) commonly used type of fertilizers, increased from time to time. They further explained that the land becoming more responsive for level of fertilizer they applied and thus they obligated to reduce land for maize.

Price of improved seed: This was found to be another important constraint in the study area. As $90.3 \%$ of sample respondents reported, not only price but also availability of the required type by the producers was the major constraints in the production year. During FGD farmers explained that they had problems of (Limu), the required type of improved seed by the farmers.

Time of input arrival: It is known that arriving on time during sowing period is highly indispensable for farmers especially to use his time wisely. However, survey result showed that $26.5 \%$ of sample respondents had complained as they had a problem of late arrival of inputs i.e. fertilizers and improved seed.

Limited land: Although land is a vital resource in agriculture, its accessibility and distribution is subjected to administrative law even in the country. As survey result, indicated $91.6 \%$ of sample respondents had serious land problem. And even costly for hiring as compared with costs 
for hiring and other input costs and benefits obtained. From production costs as survey result revealed about $40.2 \%$ was counted for land.

Quality of improved seed: The quality aspects of improved seed were seen from its physical appearance, crack that cannot be seedling and other foreign maters. About $41.9 \%$ of sample respondents had complain about the quality of improved seed.

Drought: Drought was not found to be a serious issue in the district. However, about $3.2 \%$ of respondents explained that late rain at sowing season leads to decrease in maize yield.

Road: Road that reaches to the fragmented field and especially during harvesting, loading using animal cart and another vehicle was found to be an important constraint for farmers. As survey result revealed about $87.7 \%$ of sample respondents reported as they had road problem to the field and to the market.

Unstable price: Ups and downs of marketing price in different seasons, ups in off seasons and downs during harvesting seasons is a common behavior for many agricultural produces particularly cereals. Farmers in the study area produce more cereals particularly, maize but as compared to their labour and cost expenses, their benefit is low.

Table 5. Major maize producers' constraints.

\begin{tabular}{lll}
\hline Major producers constraint & $\mathbf{N}=\mathbf{1 5 5}$ & \% share Rank \\
\hline Shortage of land & 142 & 91.61 \\
Price of improved seed & 140 & 90.32 \\
Road & 136 & 87.73 \\
Price of fertilizers & 134 & 86.54 \\
Quality of improved seed & 65 & 41.95 \\
Pest attack & 49 & 31.66 \\
Input arrival & 41 & 26.57 \\
Soil fertility & 36 & 23.28 \\
Flood & 19 & 12.39 \\
Drought & 5 & 3.210 \\
\hline
\end{tabular}

Constraints for Traders

As survey result indicated about $82 \%$ of respondents explained that unstable price discourage producers from engaging in maize production now a day and this in turn affects the whole business and traders explained that volatile price discourages not only traders but also producers. This was again supported by [13] and explained that there is unpredictability in maize and wheat prices and thus making spot market temporal and spatial arbitrage a risky business for value chain actors. For example, in the case of maize markets, about 6 to 33 percent (at the producer level), 0 to 72 percent (at the wholesale level) and 2 to 45 percent (at the retail level) of the overall maize price fluctuations are explained by unpredictable random price movements.

Absence of product grades: Absence of well standardized method of product measurement in the market affects trader's price in market transactions. As traders explained, products from producers have different impurities like rodent attacked, pest damaged, and mixture with rotten or decayed one during visual assessment at purchase and about $66 \%$ of respondents answered absence of fixed measurement for quality product in the market creates disagreements between producers and traders.

Presence of unlicensed traders: Traders explained that presence of unlicensed traders in the market discourage the licensed business. As survey result revealed about $72 \%$ of respondents explained that presence of unlicensed maize traders affects the business negatively and discourage licensed traders to staying in the business.

Processes of getting trade license: Traders in the study area explained that in order to have trade license there must be rent out and rented agreements especially to those who have no own warehouse. Which means traders who do not have their own warehouse must rent warehouse and have written agreement between warehouse owner and the trader? Survey result revealed that about $54 \%$ of respondents reported as they faced this procedure problem in the processes of getting license in the study area.

Difficulty of credit access: Finance plays a great role in the business world. However, as explained by traders' access for credit especially individual asking about credit for financial institutions has no acceptance but in group form. Peoples coming from different environment do not believe each other as a result accessing for finance is a constraint especially for starters. As survey result indicated about $52 \%$ of respondents explained that they had a problem of accessing credit services.

Poor market information: information flow is an engine for the business strength and sustainability. Especially in price volatile agricultural produces having up to date and current information plays crucial role. However, as survey result indicated about $64 \%$ of respondents had a complained that lack of well integrated information between and among traders creates weak business development and bankruptcy.

Absence of government support: Traders highly disagreed about government strategies and policies particularly about tax. They explained that the government focus is only on production level but no training and support to traders need on business operating, financial handling and human resource management mechanisms than posting/calling for taxpaying time. As survey result indicated about $98 \%$ of respondents explained that lack of government support leads to unable to exploit opportunities.

Road problem: Road is the basic infrastructure by connected traders with potential maize producers especially in rural traders where road is not expanded as urban areas. Though number of roads were constructed, most of them are seasonal, which means they are difficult during summer especially for animal cart transportation in rural area to the market. As survey result indicated all respondents reported road is a problem both in the market area and suppliers side to the market.

\section{Conclusion and Recommendations}

In the district sex of the household head, educational status, amount of maize produced per hectare, extension 
contact, total livestock owned, non-farm income and credit use were the determinant factors for amount of maize supplied to the market. Timely increased price of fertilizers and improved maize seed, input arrival time, limited land holding, quality of improved seed and road were among the major maize production and marketing constraints in the district. Thus, the concerned bodies in the district should coordinate their strategic plan and activities regarding maize production and marketing to address the above mentioned supply determinants and as well.

\section{References}

[1] Beza Erko, Degye Goshu, \& Moti Jaleta. 2016. Value Chain Analysis of Maize in the Case of Bako Tibe and GobuSayo Districts in Central West Ethiopia. J. Eco. And S. D. 23 (7) 21-26.

[2] Greene H. W. 2000. Econometric Analysis. 4th edn. NJ: Prentice Hall, Englewwod Cliffs.

[3] Getachew Olana, Nuri Kedir, Raya Abagodu, Basab Dasgupta, Woreku Ambelu, Okello O., \& Magut M. 2018. Report on crop availability and market analysis in Ethiopia. PP1-15.

[4] CSA (Central Statistical Agency). 2011. 'Ethiopia Agricultural sample survey 2010/ 2011. Volume VII, Report on crop and livestock product Utilization (private peasant Holdings, Meher Season)", Statistical Bulletin505, Federal Democratic Republic of Ethiopia, central Statistical Agency.

[5] CSA (Central Statistical Agency). 2017. Agricultural sample survey. 2016/17. Report on area and production of major crops
(Private peasant holdings, meher season); Volume I. Statistical Bulletin 584, Apprile 2017. Addis Ababa, Ethiopia.

[6] Daly J., Hamrick D., Gereffi G., \& Guinn A. 2017. Maize value chain in East Africa. Technical report, May 2017. F38202-RWA-1.

[7] Dawit Alemu, Chilot Yirga \& Adam Bekel. 2014. Situation and Outlook of maize in Ethiopia. Ethiopian Institute of Agricultural Research. Addis Ababa, Ethiopia.

[8] FOA (Food and Agriculture Organization). 2015. Analysis of price incentives for maize: The Food and Agriculture Organization Report. FAO, United nation, America.

[9] Haymanot Asfaw. 2014. Durum wheat value chain analysis: the case of gololcha district of bale zone, Ethiopia. MSc Thesis, School of agricultural economics and agribusiness, Haramaya University, Haramaya, Ethiopia. Pp 92-95.

[10] Tadele Melaku, Mulu Debela \& Mansingh P. 2016. Factors Affecting Teff and Wheat Market Supply in Dendi District, West Shoa Zone, Ethiopia. International Journal of Current Advanced Research. 5 (4): 811-816.

[11] USAID (United Nations Agency for International Development). 2010. Staple foods Value chains Analysis. Ethiopia, Pp 24-75.

[12] Sultan Usman. 2016. Analysis of wheat value chain: the case of Sinana District, Bale Zone, Oromia region, Ethiopia. MSc Thesis, School of agricultural economics and agribusiness, Haramaya University, Haramaya, Ethiopia. Pp 71-73.

[13] WB (World Bank). 2018. Cereal market performance in Ethiopia. Agricultural Global Practice GFA13. Pp 10-63. 